\title{
Announcing the Arrival of Social Performance from Corporate Social Responsibility via Corporate Social Performance:The Shell Nigeria Experience
}

\author{
Olusoji George $^{1}$, Nedo Osayande ${ }^{2}$, Godbless Akaighe ${ }^{3}$ \\ Department of Business Administration, University of Lagos, Akoka, Lagos, Nigeria ${ }^{1}$ \\ MD/CEO, Belemaoil Producing Limited, (Ex-Shell Nigeria General Manager), Port Harcourt, Nigeria ${ }^{2}$ \\ Lagos Business School, Pan-Atlantic University, Lekki-Epe Expressway, Lagos, Nigeria ${ }^{3}$
}

\begin{abstract}
This study examines the emergence of corporate social performance through the path of corporate social responsibility and identifies the seeming failure of both practices in alleviating the deprivation and poverty of community and environmental stakeholders in Ogoniland of the Niger Delta Region. The high expectation and desire for better standard of living in an oil producing community where governance, the rule of law and accountability mechanisms are limited has necessitated the call for a new approach to social contribution for societal development.

The study employed a qualitative approach with semi-structured interview. Specifically, the study covered the villages traversed by the Shell-owned Trans-Niger Pipeline (TNP) in Tai, Gokana, and Khana Local Government Areas of Rivers State, Nigeria. The results of the study indicate that CSR interventions of the IOCs have not provided sustainable economic development for the host communities of oil and gas fields and the interventions of the IOCs are not considered by the communities to be sustainable. On the basis of the arguments and findings of this study, we introduce Social Performance (SP) with the capacity to improve the interactions between the host communities and the IOCs in Nigeria.
\end{abstract}

Keywords: social performance; corporate social responsibility, corporate social performance; Niger Delta; Nigeria 
INTERNATIONAL CONFERENCE ON BUSINESS, MANAGEMENT AND FINANCE

UNITED KINGDOM | LONDON | March 7-9, 2019

\section{Introduction}

The rising expectation from society on corporate businesses is enormous, given the level of poverty, deprivation, lack, income inequality, environmental pollution, environmental degradation and neglect of many communities. With these concerns, more organizations are embracing the concept and practice of corporate social responsibility (CSR) (Devinney, 2009; Margolis \& Walsh, 2003; Christensen, Peirce, Hoffman, \& Hartman, 2007; Christensen, Mackey, \& Whetten, 2014).

Governments and society are pressing organizations to be socially responsible and to look after the interest of stakeholders, especially the community and environment. However, it would seem that the impact of CSR practices are not fully appreciated or reflected in many communities. This arises from the difficulty in measuring and substantiating companies' CSR contributions beyond their claims, especially when juxtaposed against the little practical evidence and the pitiable living conditions in many communities (Ite, Osayande \& Onaolapo, 2015; Idemudia \& Ite, 2006).

The popularity of the concept of corporate social responsibility is enormous in business and political discuss, so much so that public interest and expectations of corporations' CSR has soared in the last couple of decades (McWilliams, 2014; Ragas, \& Culp, 2014; Tai, \& Chuang, 2014; Schrempf-Stirling, Palazzo, \& Phillips, 2016; Steenkamp, 2017; Zentes, Morschett, \& Schramm-Klein, 2017; Gupta, Briscoe, \& Hambrick, 2017).

In the case of International Oil Companies (IOCS) operating in developing countries, the criticisms have continued on what the impact of their CSR programs are, and how much is spent on CSR in the communities, these being examined from the level of development of such regions, without putting in perspective the responsibility of government and other state institutions to also develop the communities. The criticisms of the operations of IOCs have come from host communities, opinion leaders, industry observers and scholars (George \& Amujo, 2012; Eweje, 2007; Kolstad, \& Kinyondo, 2016; Jamali, Lund-Thomsen, \& Jeppesen, 2017; Reddy, \& Xie, 2017).

The criticism of corporate social responsibility by Clarkson (1995) and Votaw (1973) are in the same direction that "the term is a brilliant one; it means something, but not always the same thing, to everybody. To some it conveys the idea of legal responsibility or liability; to others it means socially responsible behavior in an ethical sense; to still others, the meaning transmitted is that of "responsible for", in a causal mode; many simply equate it with a charitable contribution" (Votaw, 1973, p. 11). Caroll (1979) classifies CSR models into economic, legal, ethical and discretionary dimensions. Clarkson (1995) argued that it is difficult to measure, and tested the effectiveness of theses dimensions in the environment, and suggested that no matter how much IOCs spend on CSR, other stakeholders may feel that 


\section{INTERNATIONAL CONFERENCE ON BUSINESS, MANAGEMENT AND FINANCE}

\section{UNITED KINGDOM | LONDON | March 7-9,2019}

the IOCs have not done enough or they are "spending peanuts" in the environment in which they operate, just to justify their efforts on CSR. Therefore, there is need for a review of the interaction approaches between the IOC's and host communities.

Within the Nigerian context, crude oil was discovered in Oloibiri, now in Bayelsa State of Nigeria in 1956 by the then Shell-BP and exportation started in 1958. This attracted the increased presence of other IOCs in the country and later gave rise to serious environmental issues in the oil producing communities such as oil spillage, gas fairing, waste water pollution, land degradation, soil fertility loss and other environmental degradation (Kadafa, 2012). These issues brought agitations by stakeholders as to how much the IOCs should give back to the communities when examining the state of development of the region in comparison with other oil producing countries around the world.

From the perspective of the IOCs, their record shows that they have invested heavily in CSR initiatives in the region and taken measures to manage the associated environmental footprint. Available evidence from the oil and gas industry shows the presence of partnership schemes between the IOCS and government on community development projects and that the CSR programs have explored corporate philanthropy, stakeholder management, strategic social investment and other industry wide collaboration on community development, with huge cost implications and increasing budgets on CSR (Ite, et al, 2015).

In furthering the argument, one would assume that good CSR practice by IOCs in the Niger Delta area would sufficiently benefit all stakeholders. Results have however shown that IOCs like the Shell Petroleum Development Company Ltd. and her other affiliates in Nigeria (Shell) have not sufficiently reaped the expected recognition and benefits in their CSR endeavors. The intended non-corporate beneficiaries have also been left generally dissatisfied. The business climate has deteriorated to the point of massive Oil Mining Lease or acreage divestments by Shell and other IOC's like Total, Agip, Chevron, and Phillips. The delivered CSR efforts, whether or not properly executed, have combined community dissatisfaction with government dismal performance leading to societal disillusionment (Lindén, \& Pålsson, 2013; Frynas, 2005; Ite, 2004).

Consequent on these, workers have suffered kidnappings, oil facilities bombed, and militancy and restiveness increased in the area in the past decade since kidnapping of oil expatriates in Nigeria first made news headlines in 2006. This has not yet abated. If these CSR and CSP efforts over the years are contested, and criticized for not leading to the much desired sustainable development by stakeholders, especially the local community, what next? 
INTERNATIONAL CONFERENCE ON BUSINESS, MANAGEMENT AND FINANCE

UNITED KINGDOM | LONDON | March 7-9, 2019

\section{This present study}

This study examines the concept of corporate social responsibility and how it has transcended to corporate social performance in literature and examines the argument of community interactions and satisfaction with the applications of CSR initiatives by companies operating in the environment. This will lead us to suggesting how social performance can be the new discourse in collective partnership by all organizations and individuals in developing society, beyond the focus of only "corporate" organizations.

As the continuing interactional challenges between IOCs and their Niger Delta host communities and CSR as currently practiced are clearly sub-optimal, this research will attempt to find out why and what can be done to address the inadequacy of CSR. This paper argues that the logical improvement direction- beyond CSR- would be Social Performance. There is need for broadening the concept of CSP to SP to cater for not-for profit and other organizations.

This study attempts to introduce the desired new approach of Social Performance to societal development, building the argument beyond CSR and CSP. This study will draw mainly from the activities of Shell as it has the largest footprint in the onshore Niger Delta area of Nigeria, and has the longest presence in the region since crude oil was discovered in Nigeria.

\section{Corporate Social Responsibility}

There is no universally accepted definition of corporate social responsibility. The concept is broad, complex, dynamic and has various dimensions which continue to evolve in theory and practice (Clarkson, 1995; Margolis \& Walsh, 2003; Orlitzky, Schmidt, \& Rynes, 2003; Matten, \& Moon, 2004; Boulouta, \& Pitelis, 2014; Reddy, \& Xie, 2017).

World Business Council for Sustainable Development (WBCSD) defined CSR by businesses "to behave ethically and contribute to economic development while improving the quality of life of the workforce and their families as well as of the local community and society at large" (Holme \& Watts 2000, p. 8). In another perspective, Hopkins (2003) argues that CSR should include the macro-level responsibility to create a better standard of living for the people while the profitability of the businesses remains sacrosanct. This implies that the welfare of external stakeholders should be as paramount to business corporations as their profitability.

The British Government in a related argument conceptualized CSR as "the voluntary actions that business can take, over and above compliance with minimum legal requirements, to address both its own competitive interests and the interests of wider society" (Business Innovation and Skills 2008, p. 5), while the European Commission explained CSR to mean "the 


\section{INTERNATIONAL CONFERENCE ON BUSINESS, MANAGEMENT AND FINANCE}

\section{UNITED KINGDOM | LONDON | March 7-9,2019}

responsibility of enterprises for their impacts on society', with the aim of 'maximizing the creation of shared value for all stakeholders and society at large" (EC, 2011).

The World Business Council for Sustainable Development (WBCSD 2004) further defines CSR "as the commitment of a business to contribute to sustainable economic development, working with employees, their families, the local community and society at large to improve their quality of life." (p. 3). This definition emphasizes social dimension and stakeholder welfare in such a way that human rights, environmental preservation and community development are vital for the performance of CSR initiatives (Servaes, \& Tamayo, 2013). This has been justified by other authors (Freeman, 1984; Griffin \& Mahon, 1997; Jensen, 2001; Dahlsrud, 2008).

In spite of the different perspectives on CSR, Dahlsrud (2008), in his 5-dimensional content analysis of existing CSR definitions - environmental, social, economic, stakeholder, and voluntariness - using frequency counts concluded that the existing definitions are to a large degree congruent. The argument is that the confusion is literature is not so much about how CSR is defined, as about how CSR is socially constructed in different contexts.

The argument of the seeming convolution of the application of CSR has further been acknowledged by scholars, raising doubts about the foundations of CSR that have not clearly explained why firms continue to engage in CSR activities and have not changed the focus on the antecedents of CSR with strong and justifying business strategies (Christensen, et al, 2014; Margolis, Elfenbein, \& Walsh, 2009; Margolis \& Walsh, 2003; McWilliams, Siegel, \& Wright, 2006). This is from the point of view that firms are pressured to engage in CSR by the society only for them to be criticized for not doing enough in CSR activities for the environment and the community.

\section{From Corporate Social Responsibility to Corporate Social Performance}

Corporate Social Performance is a "multidimensional construct", which is difficult to measure (Waddock, \& Graves, 1997, p. 304; Wood, 1991). Corporate Social Performance has become important in predicting outcomes of firms in relation to societal goals and expectation, including the attraction of job seekers (Jones, Willness, \& Madey, 2014), the assessment of corporate reputation of firms beyond their corporate social responsibility initiatives and efforts (Wang, \& Berens, 2015) and financial performance (Orlitzky, Schmidt, \& Rynes, 2003; Ramchander, Schwebach, \& Staking, 2012; Surroca, Tribo \& Waddock, 2010; Luo, Wang, Raithel, \& Zheng, 2015). 


\section{INTERNATIONAL CONFERENCE ON BUSINESS, MANAGEMENT AND FINANCE}

\section{UNITED KINGDOM | LONDON | March 7-9,2019}

Corporate Social Performance is defined as "a business organization's configuration of principles of social responsibility, processes of social responsiveness, and policies, programs, and observable outcomes as they relate to the firm's societal relationships" (Wood, 1991; p. 673). CSP is explained as the application of the tenets of CSR to bring sustainable social programs, policies and actions to improving community relations with host communities and the operational environment (Wood, 1991; Wang, \& Choi, 2013). Scholars have continued to show interest in CSP (Wang, \& Choi, 2013; Jones, Willness, \& Madey, 2014) while some studies have examined the relationship between CSR and CSP, with results indicating a positive relationship between them (Orlitzky, Schmidt, \& Rynes, 2003; Roman, Hayibor, \& Agle, 1999; Margolis \& Walsh, 2003).

CSP as an extension of CSR comprised of a range of view to be able to assess a company's social performance. CSP is described as a multidimensional construct which involves initiatives undertaken by a corporate organization in the dimensions of the natural environment, how employees are treated, workplace diversity and customer satisfaction through product offering (Meijer \& Schuyt, 2005). Boulouta (2013) argue that CSP "is seen as a composite score from a selection of metrics representing a broad range of economic, social and environmental impacts caused by business operations" (p. 186). This raises the argument of impact assessment of CSP as in the case of CSR from the perspective of the community. How impactful are the company's actions, programs and policies to positively change the society? In many communities, the level of need and deprivation in the society is so engrained that the actions of corporate organizations are like a drop in the ocean. Thus, the feedback also seems negative on how much the organizations have done to lift the standard of living of the community and environment. It is from this trend of argument that portrays CSP and CSR as insufficient to meet societal expectations that we introduce the possible arrival of SP, to accommodate all members of society to meet societal expectations.

\section{Announcing the Arrival of Social Performance from CSR via CSP}

The concept of social performance is missing in mainstream literature and we argue that the principles of corporate social performance should be extended beyond corporate organizations, to cover individuals, non-governmental organizations, military organizations, cultural organisations, religious organization and individuals, to take care of the environment and local communities in partnership with corporate organizations and state actors.

In the case experience of Shell Nigeria, the investments in CSR have yielded very little result in terms of harmonious relationship with host communities in the Niger Delta area. Shell Nigeria spends over $\$ 70 \mathrm{~m}$ per year on CSR efforts covering 27 community health facilities, Shell education programs (like scholarships, professorial chair endowments, etc.), and economic empowerment schemes like LiveWIRE (which provides 


\section{INTERNATIONAL CONFERENCE ON BUSINESS, MANAGEMENT AND FINANCE}

\section{UNITED KINGDOM | LONDON | March 7-9,2019}

training for young entrepreneurs), agriculture, infrastructure and access to energy projects. In spite of this level of spending, Shell still has tremendous relationship challenges with her host communities (Cordova \& Hamdan, 2014).

Most CSR projects were as designed by the IOCs without necessarily being what the host communities desired. Idemudia and Ite (2006) argued that the adoption of CSR policies has failed to reduce the incidence of violent conflict between the host communities and oil companies in the Niger Delta area of Nigeria due to the failure to seek, understand and integrate community perceptions into CSR policies and practices.

Unfulfilled and/or massively delayed CSR promises have led to break-down of trust between the community and the IOCs. As community agitations worsened in the early 2000s, many Shell staff wriggled out of difficult interactional encounters in the field locations by making gratuitous promises on behalf of the company without a full realization of the implications. For example, shore protection works were promised in about 10 communities without realizing the enormous and unaffordable cost implication of the associated dredging. Many of these had to be negotiated for replacement with more feasible and affordable projects several years later. Similarly, a high level promise to provide a model secondary school in Trans-Amadi area of Port Harcourt, Nigeria to support the efforts of the Rivers State Government remains unfulfilled.

The unrealisable expectancy by communities for the IOCs to assume the role of governments as it relates to the provision of infrastructure, capacity development and other usual governmental provisions has not helped the negative perception of IOC societal contribution. The absence of facilities like schools in some remote communities has been blamed on the perceived non-responsiveness of IOCs like Shell rather than government. The lackadaisical attitude and lack-luster CSR performance of the IOCs in the years before the onset of militancy and the poor handling of the community agitations (like the Ken SaroWiwa's Movement for the Survival of Ogoni People's protest) culminated in the breakdown of law and order to the extent that CSR was no longer sufficient to douse the tension.

Clearly CSR and CSP as currently practiced needs to be improved to meet the current challenges (Frynas, 2005; Garvey, \& Newell, 2005; Idemudia, 2011; Jamali, Yianni, \& Abdallah, 2011; Jamali, et al., 2017). We proposes that CSR and CSP practices be replaced by Social Performance (SP), which is here defined as the extent to which organizations positively impact communities, employees, consumers, the environment and other stakeholders, especially in places where governance, the rule of law and accountability mechanisms are limited, as they simultaneously pursue their goals and objectives. 
INTERNATIONAL CONFERENCE ON BUSINESS, MANAGEMENT AND FINANCE

UNITED KINGDOM | LONDON | March 7-9,2019

This definition of "organizations" therefore expands the scope beyond "corporate organizations" and "responsibility of corporate organizations" as constituted in CSR definitions in mainstream literature. Therefore, all organizations, corporate, non-profits, religious, social, cultural, political, and non-registered businesses are covered in the conceptualization of social performance. Clearly, to meet societal expectations, we argue that individual, groups, societies, religious organizations, sports associations, philanthropists and the corporate world can benefit from coalitions and synergies to achieve much greater effectiveness in meeting societal and environmental needs beyond what CSR and CSP offers.

\section{Shell Petroleum Development Company in Nigeria (in Ogoniland)}

The Royal Dutch/Shell Group founded Shell D'Arcy, in 1936, and became the first Shell Company in Nigeria. In November 1938, Shell D'Arcy was granted Exploration license to prospect for oil throughout Nigeria with the first commercial oil field discovery at Oloibiri in January 1956. A name change was effected in April 1956 with the company becoming the Shell-BP Petroleum Development Company of Nigeria Limited (Umejesi \& Akpan, 2013).

The first Ogoniland oil commercial production was from Bomu Field at K-Dere in 1958. Oil production by Shell continued in Ogoniland from the Bomu, Bodo West, Tai, Korokoro, Yorla, and Lubara Creek Fields until 1993, when the Movement for the Survival of Ogoni People (MOSOP) under the leadership of Ken Saro-Wiwa mobilized a successful national and international campaign against the Nigerian government and Shell, citing inadequate benefits, environmental degradation and underdevelopment. (The generally held view is that the Wiwa-led protest was non-violent. The book "Witness to Justice: An Insider's Account of Nigeria's Truth Commission" by Catholic Bishop of Sokoto Diocese Matthew Hassan Kukah published 2011 contradicts this view). Shell discontinued further oil production from Ogoniland but retained the Trans-Niger Pipeline (TNP) network which transports crude oil from non-Ogoni fields to the north, through Ogoniland, to the Bonny Terminal at the coast. See map attached 


\section{ICBNAF}

INTERNATIONAL CONFERENCE ON BUSINESS, MANAGEMENT AND FINANCE

UNITED KINGDOM | LONDON | March 7-9,2019

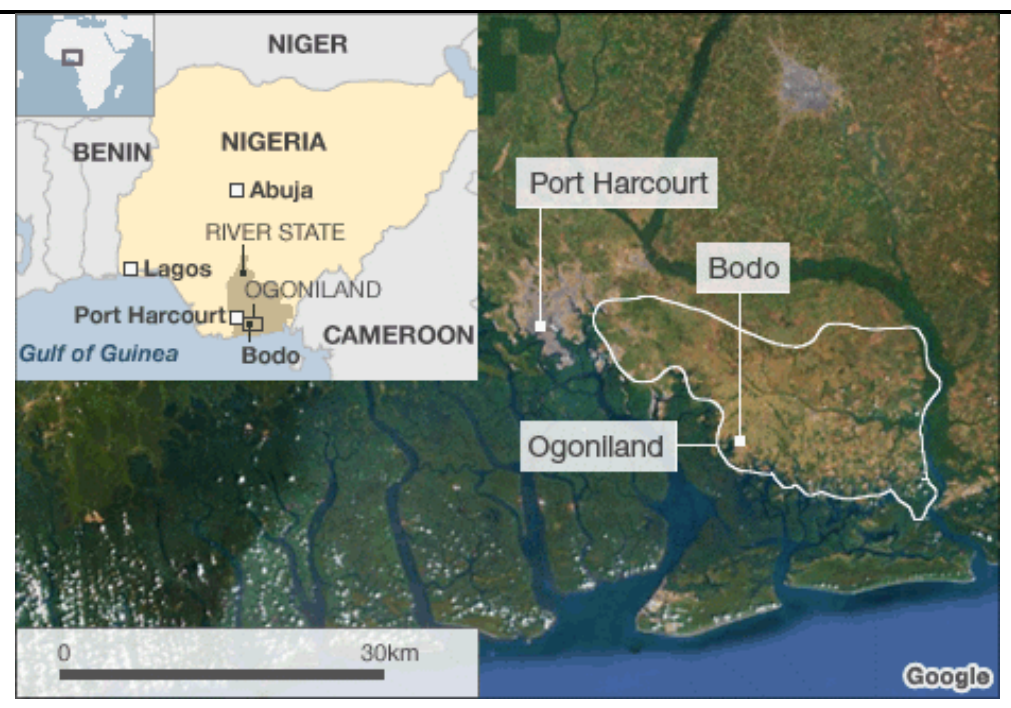

Fig. 1. Ogoni area map

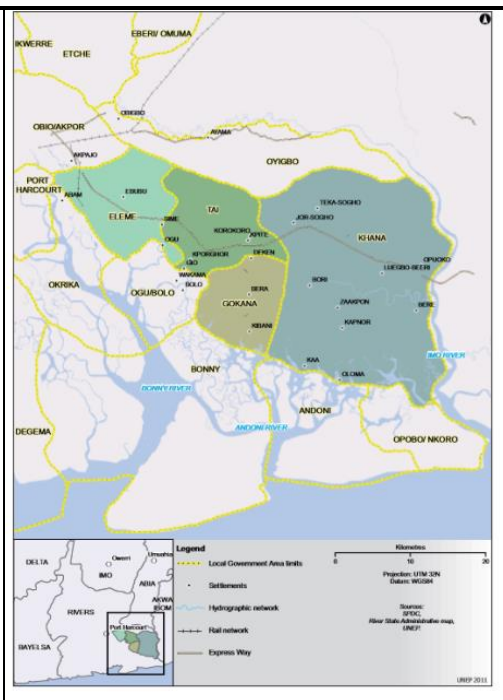

Fig. 2. Ogoni Local Government Areas

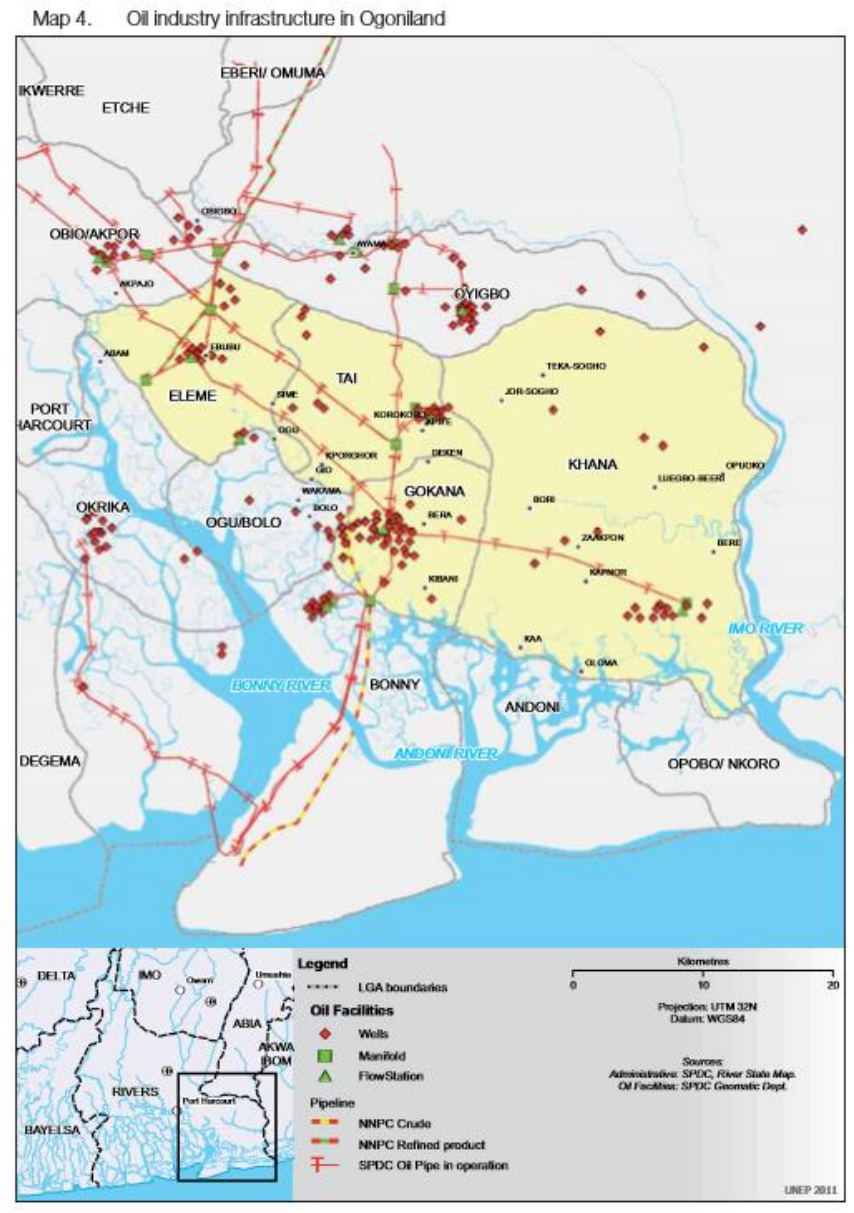

Fig. 3. Oil Industry Infrastructure in Ogoni (including the Trans Niger Pipeline) 


\section{INTERNATIONAL CONFERENCE ON BUSINESS, MANAGEMENT AND FINANCE}

\section{UNITED KINGDOM | LONDON | March 7-9,2019}

Shell-BP was changed to The Shell Petroleum Development Company of Nigeria (SPDC) in December 1979 when the General Olusegun Obasanjo military administration nationalized British Petroleum (BP) interests in Nigeria in connection with fighting Apartheid in South Africa. SPDC is the Operator of an unincorporated Joint Venture between the Nigerian National Petroleum Corporation (NNPC, representing the Federal Government of Nigeria (55\%), Shell (30\%), Total (10\%), and Agip (5\%) in the assigned Oil Mining Leases in onshore and shallow water Nigeria following the Sixth Participation Agreement in June 1993. Thus the commercial interests in the Ogoniland oilfields (and elsewhere in the Niger Delta) under the SPDC Joint Venture are as distributed above, although SPDC is the Operator, and bears the brunt of much criticism.

Boele, Fabig, and Wheeler (2001) observed that since 1993, Shell has re-invented its corporate strategy in line with principles of sustainable development and it has committed to a level of stakeholder engagement on its environmental and social performance which would have been unthinkable in 1995. However, there is still little trust between the company and the Ogoni people and their representative organization, MOSOP.

\section{Methods}

The study employed a qualitative research methodology from selected stakeholders in Ogoniland of Niger Delta area of Nigeria. Face-to-face interviews of core informants (who were drawn from CSR recipients, traditional rulers, youth leaders, religious leaders, NGOs active in the Oil Companies CSR space, and IOC staff) was conducted. The researchers adopted a narrative analysis of the data following the tradition of Bryman and Bell (2007), and Ubberman and Miles (2002). Key interviews were voice-recorded. Some respondents elected to send their responses in writing. The names of the participants are withheld in the study in line with the principles of anonymity and confidentiality of researc. Emphasis was placed on understanding the opinion, reasons behind the opinion and the context of the study. This was communicated to the study participants. The face-to-face interviews provided the opportunity to additionally observe associated voice tonality, gesticulations, and posture of respondents to help a deeper understanding of their viewpoints. These opinions were collated using thematic approach of qualitative analysis whilst being reported in the language of the informants as much as possible. The study locations were villages traversed by the Shellowned Trans-Niger Pipeline (TNP) in Tai, Gokana, and Khana Local Government Areas of Rivers State. These are areas covered by the Shell Nigeria Global Memorandum of Understanding (GMOU) in 4 Community Development Board (CDB) groups named Eleme, Gokana-1, Gokana2 and Tai. 


\section{INTERNATIONAL CONFERENCE ON BUSINESS, MANAGEMENT AND FINANCE}

\section{UNITED KINGDOM | LONDON | March 7-9,2019}

Care was taken to have representative responders from all four GMOU cluster groups in Ogoni, traditional rulers, youths, and women groups. Many respondents were initially reluctant to participate on discovering that the survey had to do with IOCs, and in particular, Shell. There was an observable discomfort at the mention of the 'Shell' name. However field workers devised ways to secure their participation. Most matured minds were however eager to participate and even helped with educating those who were reluctant of the need to participate in the survey in order to inspire a change. The general comments from respondents pointed towards the need for infrastructure provision, scholarships opportunity expansion, and more employment opportunities. They also decried the use of proxies by IOCs (in particular Shell) in engagement with the communities rather than direct contact for needs assessment.

\section{Findings}

For the provision of qualitative data, the contributions from the core-informants were either in the form of written responses or face-to-face interviews. Some respondents preferred to submit written responses to the standardized questions. These respondents were mostly subject matter experts who have extensive experience in the IOC-Host CommunitiesCSR space.

Table 1 Qualitative data presentation

\section{Group}

1 NGO
Respondent(s)

1. Rev Fr., (Director Stakeholder Alliance for Corporate Accountability (SACA)).
2. Mr. I.S. Country Director Stakeholder .Network Democracy
Mode

Written submission

\section{Issues}

a. Poor communications: Insincere. Poor listening.

b. No inclusive participation of communities.

c. Delayed/slow responses.

d. Inadequate compensations.

e. Unrealistic demands of stakeholders.

f. IOC denial of oil spills due to equipment failure, not every spill results from sabotage.

g. Community engagements via middlemen with vested interest.

h. Militarisation of the Delta. Over-dependence of IOCs on the Government Security 


\section{INTERNATIONAL CONFERENCE ON BUSINESS, MANAGEMENT AND FINANCE}

\section{UNITED KINGDOM | LONDON | March 7-9,2019}

$2 \mathrm{IOC}$

Corporate viewpoint

\section{Shell Community} Relations Manager.

4. Corporate CSR practitioner.

3 Traditional rulers/ GMOU Cluster leads
5. HRH Chief (The Paramount Ruler of Mogho, Ogoni).

6. M.S. K. (Chairman Bodo Council of Chiefs and elders / Ogoni GMOU CDB

Chairman/ Gokana-2 Cluster Lead).

7. Hon. D. N., (Chairman of Eleme GMOU

Development Cluster).
Forces (who have a strangle hold on the IOCs).

Communities feel they are a conquered people living in a conquered territory.

i. Poor relationship/confidence with local communities.

j. Excessive litigation between IOCs and local communities in a weak, cumbersome and unreliable judicial system.

k. More ADR like the Bodo Mediation process.

I. Inadequate legacy projects/interdependency.

m. Support for criminality by supporting gangs and cult groups.

n. Inadequate transparency and accountability.
Written submission

Face-to-face recorded interview a. Unrealistic expectations from host communities.

b. Insecurity in the delta

c. Vandalism.

d. Weak governance.

e. E\&P activities result in environmental, health and economic discomfort due to gas flaring, oil spills, wastes, social impacts.

a. GMOU is failing because Shell is not paying the Development fund as contracted.

b. GMOU leadership now threatened as dissatisfied youths accuse them of GMOU funds theft.

c. Oppression by Shell. Shell faces are shining, while those of Bodo people are lean.

d. Shell creating disharmony in the community by dealing with multiple structures outside the GMOU construct, 
INTERNATIONAL CONFERENCE ON BUSINESS, MANAGEMENT AND FINANCE

\section{UNITED KINGDOM | LONDON | March 7-9,2019}

8. Dr. J. B. (RVSG

Commissioner for

Chieftaincy Affairs and

former GMOU Cluster

lead for Tai).

9. HRH B. O., (The

paramount ruler of

Eleme, in the Eleme

GMOU area)

4 Religious leader
10. Rev. Fr. St. Patrick Catholic Church, Bodo.

e.g. the clean-up effort and other projects are not through the GMOU.

e. GMOU-based surveillance contract is delivering increased TNP uptime for Shell, yet Shell is not paying Development fund.

f. Scholarships and WAEC registration payments are on, but communities need much more.

g. Not comfortable with GMOU execution.

h. Community not given chance to itemise needs. Prefer roads and electricity for which GMOU funds are not enough. So nothing tangible is being achieved.

i. Need more engagement.

j. Indorama in Eleme doing better than Shell.

k. Underground water is polluted.

Face-to-face recorded interview a. Communities feel IOCs are exploiting them of their oil.

b. Resource control by communities lacking. Need to recognise that oil belongs to the communities.

c. GMOU in Bodo is great, but more needed.

d. Not recruiting enough qualified community people.

e. Communities feel IOCs staff and leadership are dominated by 'outsiders' from SW Nigeria.

f. Ogonis are smart. It is not easy to satisfy the want of smart people. 
INTERNATIONAL CONFERENCE ON BUSINESS, MANAGEMENT AND FINANCE

UNITED KINGDOM | LONDON | March 7-9,2019

5 Youth

Leaders

11. Mr P. L. and

12. Barida Gima

6 Women rep.

7 General remarks from others.
Face-to-face

Recorded interview

Interview

13. Madam B. L.

14. Community members

Written submission a. Inability/refusal to provide social amenities: Roads, Not enough scholarships. Neglect of Ogonis over the years.

b. Environmental damage: Spills.

c. GMOU awareness is low, only favours "insiders" and relatives of Cluster leaders. Limited in reach.

d. 50-70 surveillance job slots for Bodo is good but too few.

e. Prefer projects that will touch generality of persons like water, markets, etc.

f. Stop engaging through proxies. "Come down to the ground and not send people".

g. Need employment for all graduates. Surveillance guards are too few. 500 youth employment over the TNP in Ogoni not enough.

h. Shell needs "honesty and sincerity of purpose"

a. Shell should take care of widows, orphans and poor people.

b. Our fishing has been destroyed.

c. We want Shell to pay us money every month.

a. Provide amenities, electricity, roads, Health centre.

b. Pay compensation (monthly). 6

c. Provide employment, eradicate poverty.

d. Build capacity, provide scholarships.

e. Clean the environment.

f. Build motherless babies 3 home/provide for widows 2

g. Improve security. 
INTERNATIONAL CONFERENCE ON BUSINESS, MANAGEMENT AND FINANCE

UNITED KINGDOM | LONDON | March 7-9,2019

\section{Discussion of the Findings}

The response table shows that the need for the provision of basic amenities like electricity, good roads, and health facilities tops the general requests of the Ogonis. The nearabsence of government has led the people to shift the responsibility for this provision to Shell as this is the government they see, and who has some modicum of response when community pressure is mounted. And why not, when Shell (like other IOCs) is supposed to deliver Corporate Social Responsibility? The overwhelming "responsibility" expectation by the host communities bequeathed on Shell by "CSR" is not helpful to the eventual outcome of ShellOgoni relations, as with elsewhere in the Niger Delta.

The general feedback from the interaction with the community is that "Shell should compensate Ogoni". It is probable this compensation fixation is fuelled by the Shell payment of $f 55 \mathrm{~m}$ to the Bodo community of Ogoni in the Leigh Day-led Bodo litigation settlement of 2014 , or (in the view of the researchers), the merited delta-wide resource control agitation.

The desire to reduce poverty via the provision of jobs is reflected in the interview with the youth leaders in the community- "Provide employment, eradicate poverty". As the upstream oil industry is a lot more capital intensive than human resource intensive, the desired increase in employment would need to come from elsewhere like agriculture, manufacturing and services. Although the effective working of the upstream oil industry would play a huge role in providing the finance and raw materials leverage for these, a lot more depends on governments' political will to bring these about than on the IOCs like Shell.

Table 2: Summary of remarks by stakeholders

\begin{tabular}{|c|c|c|c|}
\hline \multicolumn{4}{|c|}{ gavie 2.} \\
\hline & & $\mathbf{F}^{*}$ & $\%$ \\
\hline & Provide amenities, Electricity, Roads, Health center. & 6 & 27.27 \\
\hline & Pay compensation (monthly). & 4 & 18.18 \\
\hline & Provide employment, eradicate poverty. & 4 & 18.18 \\
\hline $\begin{array}{l}\text { Summary } \\
\text { of remarks }\end{array}$ & Build capacity, provide scholarships. & 3 & 13.64 \\
\hline & Clean the environment. & 2 & 9.09 \\
\hline & Build motherless babies home/provide for widows. & 2 & 9.09 \\
\hline & Improve security. & 1 & 4.55 \\
\hline
\end{tabular}

Summary

of remarks

\section{Table 2: Summary of remarks by stakeholders}




\section{INTERNATIONAL CONFERENCE ON BUSINESS, MANAGEMENT AND FINANCE}

\section{UNITED KINGDOM | LONDON | March 7-9,2019}

From the data summary, the following conclusions are drawn:

- CSR interventions of the IOCs have not provided sustainable economic development for the host communities of oil and gas fields. The host communities to the oil and gas fields in Ogoni and elsewhere in the Niger Delta feel that they have remained economically marginalized. This also reflects in the clamor for resource control as the hydrocarbon is extracted from their land.

- CSR activities and interventions of the IOCS are not considered by the communities to be sustainable. These interventions are considered by the host communities to be paltry, token and not sufficient to make sufficient impact that may lead to sustainability.

- It is manifestly obvious that the level of criticism of Shell by the Ogonis is high, and has not abated since the cessation of oil and gas production since the Ken Saro Wiwa-led agitations. This is in line with the observation by Idemudia and Ite (2006) that the adoption of CSR policies has failed to reduce the incidence of violent conflict between the host communities and oil companies in the Niger Delta, Nigeria due to the failure to seek, understand and integrate community perceptions into CSR policies and practices.

- To the extent that the Ogoni fields have remained shut-in since 1996, Shell business goals cannot be said to have been met in the area. And given the spate of accelerated acreage divestments in the last decade, the challenge to the Shell business goals in the Niger Delta transcends the Ogoni area experience. Even Total (Elf) and Eni (Agip) have similarly in conjunction with their Joint Venture Partner Shell and in their separate joint ventures with NNPC (in which Shell is not involved) also embarked on divestments. One can therefore deduce that in-spite of the claimed altruistic reasons for the IOC acreage divestments, IOC business goals in the onshore Niger Delta are not being met. Thus CSR generally have not significantly contributed positively to the achievement and delivery of IOC business goals.

- Beyond CSR, the key attributes of Social Performance of organizations being in the space where communities are comfortable that their interest is considered alongside organizational thought and actions, where they are positioned as partners and/or co-owners rather than observers, received significant welcome. Thus, Social Performance (SP) has the capacity to improve the interactions between the host communities and the IOCs in Nigeria.

- Using a community participatory approach in managing the surveillance of the Trans-Niger Pipeline (under the Ogoni area GMOU construct) resulted in cost savings, increased community employment, more pipeline uptime and less oil production deferment. A deepening of the ownership construction of the hydrocarbon resources is likely to similarly offer less criticism, less oil and gas infrastructure vandalism, and significantly increased production for the benefits of all sides.

- Matched with the unfavorable outcomes, the Shell CSR spend in Ogoniland must have a significant as-yet unquantified proportion of "waste". It is likely that it is this 
INTERNATIONAL CONFERENCE ON BUSINESS, MANAGEMENT AND FINANCE

UNITED KINGDOM | LONDON | March 7-9,2019

wastage that is fuelling the continuing disaffection and poor business climate. Adopting SP approaches would help to reduce this waste.

\section{Conclusion}

This research used qualitative method to test the effectiveness of CSR approaches using Shell interactions with the Ogoni communities in the Trans Niger Pipeline transects areas of the Niger Delta. The research found that much leaves to be desired with the current CSR approach, it suggests a replacement mind-set where the actions and thinking of organizations will demonstrably show that the interest of the host communities are considered as part of the tactical and strategic business processes. Such new approach has been describes as Social Performance. This new approach also does away with the "responsibility" burden of CSR.

Social Performance (SP) has been defined by the authors as the extent to which organizations positively impact communities, employees, consumers, other stakeholders and the environment, especially in places where governance, the rule of law and accountability mechanisms are limited, as they simultaneously pursue their goals and objectives. This study demonstrated that SP has the potential to deliver superior benefits to all stakeholders than CSR and thus canvasses for the embedment of SP practices in all facets of IOC organizational interactions with host communities. The following conclusions have been inferred from this study:

- CSR interventions of the IOCs have not provided sustainable economic development for the host communities of oil and gas fields.

- CSR activities and interventions of the IOCs are not considered by the communities to be sustainable.

- CSR activities of IOCs in the Niger Delta have not reduced criticisms against them.

- CSR activities have generally not significantly contributed positively to the achievement and delivery of IOC business goals.

- Social Performance (SP) has the capacity to improve the interactions between the host communities and the IOCs in Nigeria.

This research concludes that CSR as currently practiced by Shell and other IOCs in Niger Delta needs to give way to SP which holds significant business and society beneficial promises. Implementing and embedding the SP ethos still requires deep thinking and planning. The SP ethos of partnership, co-ownership, sustainable deal-reaching and long-term relationshipbuilding contrasts with the more transactional, short-term focused, one-sided profit driven, bribe-leaning CSR. The embedment of the SP approach offers 


\section{INTERNATIONAL CONFERENCE ON BUSINESS, MANAGEMENT AND FINANCE}

\section{UNITED KINGDOM | LONDON | March 7-9,2019}

significant benefits to all parties in the Niger Delta and nationally. The good parts of CSR should be incorporated into SP. For example, the delivery mechanism like the GMOU and progress measurements approaches like SCOTDI (The Shell Community Transformation and Development Index) (Idemudia \& Osayande, 2016).

Some recommendations have been listed below and assigned to three different groups: Companies and organizations, Government (covering local, state and national), as well as the communities. It is by no means the intention that these are hard boundaries as the implementation of these recommendations requires cross-boundary interactions and cooperation in many cases.

\section{Companies and Organizations:}

The operationalization of the SP approach still requires deep thinking so as to avoid the pitfalls of CSR like high-jack by benefit captors, the inadvertent empowerment of miscreants and henchmen, inadequate community involvement and engagement, etc. IOCs should design out room for benefit capture by undesirable actors via direct town hall engagements, rather than working via proxies.

The achievement of the Resource Control agenda or other constructs of resource coownership with the host communities require careful management in the selection of representation and areal boundaries. Emphasis must be based on the building of sustainable self-renewing societal institutions rather than dealing with henchmen.

IOCs continuously invest in technical data gathering and analyses via repeated seismic acquisition, oil-well measurements etc., to the point of achieving the digital oilfield concept. On the other hand, scant attention is paid to the gathering and analysis of social data. To avoid massive and painful occasional adjustments from non-technical risks or even organizational mortality, continuous social data gathering and analyses must be brought to the level of attention that technical data enjoys.

Compared to local communities in developing countries, IOCs have superior global and long-standing institutional know-how. They must be ready to help host communities (and governments) willingly and voluntarily rather than take undue advantage because of shortterm profit maximization. This is a key opportunity area for IOCs to visibly demonstrate that they have the interest of the community at heart. SP-thinking must displace the promotion of antisocial practices of multinational corporations like IOCs in Nigeria as opined by Otusanya (2011). The early adoption of urban planning and field development concepts in oil field development and the donation of work by-products as listed in Appendix -1 would be helpful.

As Shell has repeatedly stated her desire not to return to oil and gas production from Ogoni, the eventual replacement operator would do well to: 


\section{INTERNATIONAL CONFERENCE ON BUSINESS, MANAGEMENT AND FINANCE}

\section{UNITED KINGDOM | LONDON | March 7-9,2019}

A. Connect with communities directly rather than using proxies by:

- $\quad$ Conducting periodic Open Parliament sessions and periodic social surveys (much the same way technical data is gathered continuously to optimize field operations).

- Deploying social media communication avenues to advertise and communicate SP plans and successes. Cell phone numbers connecting via GSM cell sites in Ogoni can be preferentially targeted with short message services (SMS), WhatsApp, Instagram, Twitter, and other social media approaches.

B. Design a construct where the communities have a "skin in the game" by having a stake, and by being better represented in the staff and leadership structure of the operating company.

C. Adopt SP practices that clearly demonstrate that the company has the interest of the community at heart by actively searching out and deploying collateral benefits like interdependency electrical power, Field Development and Urban Planning practices beneficial to communities, etc.

\section{Government:}

Government must be alive to its responsibility of governance. The abdication of their role to IOCs is ultimately damaging to the national economy given that $80 \%$ of Nigeria's foreign exchange income derives from the oil and gas industry. The hither-to docility of the Niger Delta peoples must not be taken for granted. The relative lack of development of the region that lays the (current) golden eggs is a national self-deleterious sin.

Under the Resource Control Agenda, the determination of which communities benefit must be carefully articulated. Beyond the communities where the oil and gas fields are located are others who have a genuine interest by virtue of pipelines traversing their domain, oil field infrastructure like manifolds being on their land, road and water access through their communities, exposure to pollution risk from dredge-related turbidity and spills, etc.

In many communities, there is evident need for the education of the populace to recognize that the resource base of government and organizations is finite and that employment possibilities are limited and need to be shared with other host communities as well. There is a crying need for peace and security in the Delta to promote local job creation. Most E\&P companies have their headquarters in Lagos having fled from Warri and Port Harcourt, leading to massive job losses and lost business opportunities/easy access to oil and gas companies leadership.

In conjunction with the national government, the respective state governments of Rivers, Bayelsa and Delta especially must do something to improve the business environment 


\section{INTERNATIONAL CONFERENCE ON BUSINESS, MANAGEMENT AND FINANCE}

\section{UNITED KINGDOM | LONDON | March 7-9,2019}

of their states in the area of security, and harassment by state-sponsored or state-tolerated touts. In the last ten years, Warri in Delta State suffered the relocation of major and medium oil-related companies to other states with a heavy toll on the local economy and therefore employment. Shell shut down their Warri Office. Pan Ocean and Raycon moved their regional offices from Warri to Benin. In Port Harcourt, the harassment by local touts led to the relocation of service companies and their fabrication yards e.g. Ariboil and BG Technical moved to Owerri in Imo State. Successor buyers of Shell divested OMLs 18, 24, 29, respectively Eroton, NewCross and Aiteo only have scanty presence in Port Harcourt and have their headquarters in Lagos, whereas these assets were all previously managed by Shell from Port Harcourt.

Government must develop an agenda to demilitarize the Delta. This is not expected to be trivial as in the view of Inemo Samiama - a social activist - the Government Security Forces have an entrenched (pecuniary) interest in remaining in the Delta. This demilitarizing effort would need to be complimented by the IOCs being less dependent on security provision by Government Security Forces (GSFs). The lessons from this study can be extended to other industry-community interactions nation-wide thus offering a potential huge upside of national dimensions. For example, this should be useful as government pursues the development of the potentially huge solid mineral sector, still currently in its infancy.

\section{Communities:}

This research identified that many persons in the Ogoni communities expect Shell to provide them with roads, health facilities, scholarships (for all), and to put them on monthly pay! Virtually no respondent made any such demand of government. One is compelled to ask why the communities have become complacent in demanding better performance from their governments. Communities must begin to demand more from their governments (especially given that government receives over $80 \%$ of the proceeds from every barrel of oil produced onshore Nigeria).

In the interview, one of the respondents (A reverend Father) stated that his assessment is that the Bodo people of Ogoni have high intelligence quotient (IQ). This relative abundance of educated persons with high intellect must be harnessed to change the Ogoni community narrative to one of societal progress beyond reliance on the oil industry as the panacea for all problems. Improving the relationship between oil and gas companies would result in sustainable benefits for their host communities in infrastructure provision, human capacity development, reduction in social dislocation, and social development towards selfgovernance. 


\section{Ubuntu Social Performance}

This study contributes to a deepening of the academic work in CSR and the emerging SP. The concept of Ubuntu Social Performance (USP) - which relates to a Social Performance ethos where organizations in addition to traditional CSR practices, actively and deliberately search out and freely give of aspects of their normal business endeavors or by-products that positively benefits society at large - is hereby introduced. CSR as currently practiced seem to have unwittingly caused large income disparities via working through contractors or proxies rather than self-renewable community structures. To what extent this empowerment of henchmen has worsened criminality and accentuated societal dissonance, remains to be studied. It is suggested that the dark side (how CSR practice have promoted criminality, crime and terror acts by miscreants and community deviants) be investigated in remote communities where multinational companies and IOCs operate in developing countries, to substantiate the findings of this study.

The disdain for the "Responsibility" in CSR as being causative for skewed societal expectations from IOCs was not rigorously tested. This should have been done. The research supports the applications of the conclusions reached from this land based assessment in Ogoniland delta-wide. That is, also in the wet mangrove and fresh water swamps. The efficacy of generalizing the outcomes of land-based measurements to the more challenging swampy terrains of the Niger Delta require further study given the differences in transportation modes, predominant occupations, and the nature of qualitative research methodology which does not support such research findings generalizations. 
INTERNATIONAL CONFERENCE ON BUSINESS, MANAGEMENT AND FINANCE

UNITED KINGDOM | LONDON | March 7-9, 2019

\section{References}

Ahmed, S. U., Islam, Z., Mahtab, H., \& Hasan, I. (2014). Institutional investment and corporate social performance: linkage towards sustainable development. Corporate Social Responsibility and Environmental Management, 21(1), 1-13.

Boele, R., Fabig, H., \& Wheeler, D. (2001). Shell, Nigeria and the Ogoni. A study in unsustainable development: I. The story of Shell, Nigeria and the Ogoni peopleenvironment, economy, relationships: conflict and prospects for resolution. Sustainable Development, 9(2), 74-86.

Boulouta, I. (2013). Hidden connections: The link between board gender diversity and corporate social performance. Journal of Business Ethics, 113(2), 185-197.

Boulouta, I., \& Pitelis, C. N. (2014). Who needs CSR? The impact of corporate social responsibility on national competitiveness. Journal of Business Ethics, 119(3), 349364.

Bryman, A. \& Bell, E. (2007). "Business research methods”, Chicago: Oxford University Press.

Business Innovation and Skills. (2008). Corporate responsibility report. UK Government Publication. Online, http://www.berr. gov.uk/files/file50312.pdf

Carroll, A. B. (1979). A three-dimensional conceptual model of corporate performance. Academy of Management Review. 4: 497-505.

Clarkson, M. E. (1995). A stakeholder framework for analyzing and evaluating corporate social performance. Academy of Management Review, 20(1), 92-117.

Christensen, L. J., Mackey, A., \& Whetten, D. (2014). Taking responsibility for corporate social responsibility: The role of leaders in creating, implementing, sustaining, or avoiding socially responsible firm behaviors. The Academy of Management Perspectives, 28(2), 164-178.

Christensen, L.J., Peirce, E., Hoffman, M., \& Hartman, L. (2007). An analysis of ethics, CSR, and sustainability education in the Financial Times Top 40 international business schools: Baseline data and future research directions. Journal of Business Ethics, 73, 347-368.

Devinney, T. M. (2009). Is the socially responsible corporation a myth? The good, the bad, and the ugly of corporate social responsibility. Academy of Management Perspectives, 23, $44-56$

Dahlsrud, A. (2008). How corporate social responsibility is defined: An analysis of 37 definitions. Corporate Soc. Responsibility Environ. Management, 15, 1-13

European Commission. (2008a). Communication from the commission on the European competitiveness report 2008. Brussels: EC.

Eweje, G. (2007). Multinational oil companies' CSR initiatives in Nigeria: The skepticism of stakeholders in host communities, Managerial Law, 49(5/6), 218 - 235.

Freeman, R.E. (1984). Strategic management: A stakeholder approach (Pitman Publishing, Boston).

Frynas, J. G. (2005). The false developmental promise of Corporate Social Responsibility: Evidence from multinational oil companies. International Affairs, 81, 581-598. 


\section{INTERNATIONAL CONFERENCE ON BUSINESS, MANAGEMENT AND FINANCE}

\section{UNITED KINGDOM | LONDON | March 7-9,2019}

Garvey, N., \& Newell, P. (2005). Corporate accountability to the poor? Assessing the effectiveness of community-based strategies. Development in Practice, 15, 389-404.

George, O. \& Amujo, O. (2012). Thoughts on corporate social responsibility (CSR) and corporate social irresponsibility (CSI) in Nigeria. Lambert Academic Publishing.

Griffin, J.J., \& Mahon, J. F. (1997). The corporate social performance and corporate financial performance debate: Twenty-five years of incomparable research. Bus. Soc. 36, 5-31.

Gupta, A., Briscoe, F., \& Hambrick, D. C. (2017). Red, blue, and purple firms: Organizational political ideology and corporate social responsibility. Strategic Management Journal, 38(5), 1018-1040.

Holme, R., \& Watts, P. (2000). Corporate social responsibility: Making good business sense. Geneva: World Business Council for Sustainable Development

Hopkins, M. (2003). The planetary bargain: Corporate social responsibility matters. London: Earthscan

Idemudia, U., \& Ite, U. E. (2006). Corporate-community relations in Nigeria's oil industry: challenges and imperatives. Corporate Social Responsibility and Environmental Management, 13(4), 194-206.

Idemudia, U. (2011). Corporate social responsibility and developing countries: Moving the critical CSR research agenda in Africa forward. Progress in Development Studies, 11, $1-18$.

Idemudia, U, \& Osayande, G.N. (2016). Assessing the effect of corporate social

responsibility on community development in the Niger Delta: A corporate perspective. Community Development Journal, 1-18.

Ite, E. U. (2004). Multinationals and corporate social responsibility in developing countries: a case study of Nigeria. Corp. Soc. Responsib. Environ. Mgmt, 11, 1-11

Ite, U., Osayande, N., \& Onaolapo, B. (2015, August). Towards Sustainable Community Development: A Case Study of SPDC Community Transformation and Development Index (SCOTDI). In SPE Nigeria Annual International Conference and Exhibition. Society of Petroleum Engineers.

Jamali, D., Lund-Thomsen, P., \& Jeppesen, S. (2017). SMEs and CSR in developing countries. Business \& Society, 56(1), 11-22.

Jamali, D., Yianni, M., \& Abdallah, H. (2011). Strategic partnerships, social capital and innovation: Accounting for social alliance innovation. Business Ethics: A European Review, 20, 375-391

Jensen, M.C. (2001). Value maximization, stakeholder theory, and the corporate objective function. Eur. Financial Management, 7, 297-317.

Jones, D. A., Willness, C. R., \& Madey, S. (2014). Why are job seekers attracted by corporate social performance? Experimental and field tests of three signal-based mechanisms. Academy of Management Journal, 57(2), 383-404.

Kadafa, A. A. (2012). Oil exploration and spillage in the Niger Delta of Nigeria. Civil and Environmental Research, 2(3), 38-51.

Kolstad, I., \& Kinyondo, A. (2016). Alternatives to local content requirements in resource-rich countries. Oxford Development Studies, 1-15.

Lindén, O., \& Pålsson, J. (2013). Oil contamination in Ogoniland, Niger Delta. Ambio, 42(6), 685. 


\section{INTERNATIONAL CONFERENCE ON BUSINESS, MANAGEMENT AND FINANCE}

\section{UNITED KINGDOM | LONDON | March 7-9, 2019}

Luo, X., Wang, H., Raithel, S., \& Zheng, Q. (2015). Corporate social performance, analyst stock

recommendations, and firm future returns. Strategic Management Journal, 36(1), 123 136.

Margolis, J. D., Elfenbein, H. A., \& Walsh, J. P. (2009). Does it pay to be good . . . and does it matter? A meta-analysis of the relationship between corporate social and financial performance (Working Paper). Retrieved from http://dx.doi.org/10.2139/ssrn.1866371

Margolis, J. D., \& Walsh, J. P. (2003). Misery loves companies: Rethinking social initiatives by

business. Administrative Science Quarterly, 48(2), 268 -305.

Matten, D., \& Moon, J. (2004). Corporate social responsibility. Journal of Business Ethics, 54(4), 323-337.

McWilliams, A. (2014). Economics of corporate social responsibility. Edward Elgar Publishing.

McWilliams, A., Siegel, D. S., \& Wright, P. M. (2006). Corporate social responsibility: Strategic

implications. Journal of Management Studies, 43, 1-18.

Meijer M, Schuyt T. 2005. Corporate social performance as a bottom line for consumers. Business and Society 44(4), 442-461

Orlitzky, M., Schmidt, F. L, \& Rynes, S. L. (2003). Corporate social and financial performance: A meta-analysis. Organization Studies, 24(3), 403-441

Otusanya, O.J. (2011). The role of multinational companies in corrupt practice: The case of Nigeria. International Journal of Critical Accounting, 3(2-3), 171-203

Ragas, M. W., \& Culp, R. (2014). Corporate Social Responsibility. In Business Essentials for Strategic Communicators (pp. 109-122). Palgrave Macmillan US.

Ramchander, S., Schwebach, R. G., \& Staking K. (2012). The informational relevance of corporate social responsibility: evidence from DS400 index reconstitutions. Strategic Management Journal, 33(3), 303-314

Reddy, K. S., \& Xie, E. (2017). Cross-border mergers and acquisitions by oil and gas multinational enterprises: Geography-based view of energy strategy. Renewable and Sustainable Energy Reviews, 72, 961-980.

Roman, R. M., Hayibor, S., \& Agle, B. R. (1999). The relationship between social and financial performance: Repainting a portrait. Business \& Society, 38(1), 109-125.

Schrempf-Stirling, J., Palazzo, G., \& Phillips, R. A. (2016). Historic corporate social responsibility. Academy of Management Review, 41(4), 700-719.

Servaes, H., \& Tamayo, A. (2013). The impact of corporate social responsibility on firm value: The role of customer awareness. Management Science, 59(5), 1045-1061.

Steenkamp, J. B. (2017). Corporate Social Responsibility. In Global Brand Strategy (pp. 209 -238). Palgrave Macmillan UK.

Surroca, J., Tribo, J. A., \& Waddock, S. (2010). Corporate responsibility and financial performance: the role of intangible resources. Strategic Management Journal, 31(5), 463-490.

Tai, F. M., \& Chuang, S. H. (2014). Corporate social responsibility. Ibusiness, 6(03), 117.

Huberman, A. M. \& Miles, M. B. (Eds) (2002). The qualitative researchers'companion. Thousand Oaks: Sage, London, New Delhi. 


\section{INTERNATIONAL CONFERENCE ON BUSINESS, MANAGEMENT AND FINANCE}

\section{UNITED KINGDOM | LONDON | March 7-9,2019}

Umejesi, I., \& Akpan, W. (2013). Oil exploration and local opposition in colonial Nigeria:

Understanding the roots of contemporary state-community conflict in the Niger Delta. South African Review of Sociology, 44(1), 111-130.

Votaw, D. (1973). Genius becomes rare. In D. Votaw \& S. P. Sethi (Eds.), The corporate dilemma, 11 -45. Englewood Cliffs, NJ: Prentice-Hall

Waddock, S. A., \& Graves, S. B. (1997). The corporate social performance-financial performance link. Strategic Management Journal, 303-319.

Wartick, S. L., \& Cochran, P. L. 1985. The evolution of the corporate social performance model.

Academy of Management Review, 4, 758-769

Wang, H., \& Choi, J. (2013). A new look at the corporate social-financial performance relationship: The moderating roles of temporal and interdomain consistency in corporate social performance. Journal of Management, 39(2), 416-441.

Wang, Y., \& Berens, G. (2015). The impact of four types of corporate social performance on reputation and financial performance. Journal of Business Ethics, 131(2), 337-359.

Wood, D. J. (1991). Corporate social performance revisited. Academy of Management Review, 16(4), 691-718.

Zentes, J., Morschett, D., \& Schramm-Klein, H. (2017). Corporate social responsibility. In Strategic Retail Management (pp. 207-226). Springer Fachmedien Wiesbaden.

\section{APPENDIX -1}

\section{OIL INDUSTRY ACTIVITIES WITH CO-LATERAL SP BENEFITS}

\section{Exploration phase}

1. Survey pillar/coordinate densification from onshore seismic surveys. Map updates for communities, features, river boundaries, coastlines, for military and civil use, etc.

2. Elevation mapping for infrastructure placement. Regional drainage planning. The proposed Yar'Adua Airport in Bayelsa State is poorly located as the sand filling required will be enormous. Agriculture - avoid flood plains or arrange drainage. Flood level measurements, simulation and prediction (e.g. Cameroon's Lagdo Dam water release of 2013 worsening flooding in the Niger Delta).

3. Forestry studies whilst conducting seismic damages enumeration: Types and distribution of economic trees and endangered species.

4. Soil stratigraphy and type mapping for agricultural and infrastructural uses.

5. Weathering mapping to provide information for (a) sand search (b) structural strength assessment for roads, railways, and other infrastructure.

6. Bore-hole provision for potable water to communities by seismic crews. 


\section{Development phase}

7. The placement of well slot dredge spoils in locations and in such a way as to contribute to scarce above-tidal-level land for communities in the mangrove swamps.

8. The pre-planning of urban lay-outs around new land location oil and gas field development, and other major infrastructure. The preference for fixed-housing rather than houseboats for accommodating field employees in flow-stations.

9. Canalisation with community transportation in mind. The provision of alternative driveways beside pipeline right-of-ways in land areas.

10. Civil infrastructure construction like location roads, air-strips, jetties, etc. to be built with beyond-oil-industry-use in mind. The conversion of burrow pits (used for location road construction) to recreational centres or other beneficial uses as part of abandonment plans.

\section{Production phase}

11. Provision of upgraded waste disposal sites.

12. Manpower development/secondment: Nigerian content development, Economic planning teams, universities, sustainable development agencies of government, etc.

13. Social sophistication and governance.

14. Tidal/Water level gauges placed by Shell (and others) delta-wide. With divestments, these now need central collation. And will be useful to National Emergency Management Agency (NEMA), Ministry of Transport, etc. for flood prediction, monitoring, and emergency infrastructure siting/building. This was very useful in 2012 when the Niger Delta was massively flooded.

15. Methanol production: A gas business with strong SP impact as with the promotion of Clean Cookstoves usage rather than the unsustainable use of firewood which has health and neurological issues with smoke inhalation.

16. Replace House Boats as Flow station logistics bases with brick and mortar developments, preferably owned by communities and rented by oil companies. 